\title{
Do age, diabetes and left ventricular function affect the outcomes of ischemic mitral valve repair?
}

\author{
Loreta Jankauskiene $^{1,2}$, Milda Svagzdiene ${ }^{1,2}$, Edmundas Sirvinskas ${ }^{1,2}$, Sarunas Kinduris ${ }^{1,2}$, \\ Darius Adomavicius ${ }^{2}$ \\ ${ }^{1}$ Institute of Cardiology, Lithuanian University of Health Sciences, Kaunas, Lithuania \\ ${ }^{2}$ Clinic of Cardiothoracic and Vascular Surgery, Lithuanian University of Health Sciences, Medical Academy \\ Hospital, Kaunas, Lithuania
}

Kardiochirurgia i Torakochirurgia Polska 2014; 11 (3): 239-245

\begin{abstract}
Introduction: It is well documented that older age, chronic concomitant diseases (such as diabetes mellitus, chronic obstructive lung disease, etc.), and poor left ventricular function can increase the postoperative complication rate and worsen the general outcomes of coronary artery bypass (CABG) and concomitant repair of ischemic mitral regurgitation (MR).

Material and methods: Retrospective data of 394 patients after CABG and mitral valve (MV) repair (mainly annuloplasty) were analyzed. Patients were grouped according to age, diabetes mellitus (DM), and left ventricular ejection fraction (LVEF). Echocardiography data, the rate of postoperative complications (cardiogenic shock, preoperative myocardial infarction, bleeding from the gastrointestinal tract, cognitive disorders, stroke, sepsis, deep wound infection), and early and late mortality were compared between paired groups.

Results: There were no differences between age groups in reverse positive remodeling of LV. A significantly higher incidence of sepsis and deep wound infection in younger patients was observed. Patients with DM had no change in the prepostoperative NYHA class and a higher rate of perioperative $\mathrm{MI}$ $(10.3 \%$ vs. $3.1 \%$ respectively, $p<0.05)$ in comparison to patients with no DM. In all LVEF groups, MR was significantly decreased, but reverse positive remodeling of LV was pronounced only in those with "poor" and "moderately lowered" LVEF. Postoperative complications did not differ among these three groups. Conclusions: Elderly age, concomitant DM and lowered LVEF do not influence either early or late mortality, including early postoperative outcomes after MV repair for ischemic MR following CABG. Concomitant DM increases the rate of perioperative $\mathrm{MI}$ and impairs reverse remodeling of LV.

Key words: cardiac surgery procedures, ischemic mitral valve repair, risk factors, complications.
\end{abstract}

\section{Streszczenie}

Wstęp: Zostało dobrze udokumentowane, że starszy wiek, przewlekłe choroby współistniejące (takie jak cukrzyca, przewlekła obturacyjna choroba płuc itp.) oraz słaba czynność lewej komory mogą zwiększyć wskaźniki powikłań pooperacyjnych i pogorszyć ogólne wyniki operacji pomostowania aortalno-wieńcowego (coronary artery bypass - CABG) z jednoczesną naprawą niedokrwiennej niedomykalności zastawki mitralnej. Materiał i metody: Przeanalizowano retrospektywne dane 394 pacjentów po CABG i zaopatrzeniu zastawki mitralnej (głównie anuloplastyce). Pacjentów podzielono na grupy według wieku, obecności cukrzycy oraz frakcji wyrzutowej lewej komory (left ventricular ejection fraction - LVEF). Dane echokardiograficzne, wskaźniki powikłań pooperacyjnych (wstrząs kardiogenny, przedoperacyjny zawał mięśnia sercowego, krwawienie z przewodu pokarmowego, zaburzenia poznawcze, udar, posocznica, głębokie zakażenie rany operacyjnej) oraz wczesną i odległą śmiertelność porównano między sparowanymi grupami.

Wyniki: Nie stwierdzono różnic w odniesieniu do przebudowy lewej komory pomiędzy grupami wiekowymi. U młodszych pacjentów obserwowano istotnie częściej sepsę oraz głębokie zakażenia ran operacyjnych. Pacjenci z cukrzycą nie wykazywali zmian pomiędzy przed- i pooperacyjną klasą NYHA, a okołooperacyjna niedomykalność zastawki mitralnej występowała wśród nich częściej niż u pacjentów bez cukrzycy (odpowiednio 10,3\% i 3,1\%, $p<0,05)$. We wszystkich grupach LVEF niedomykalność została znacząco zmniejszona, jednakże przebudowa lewej komory była wyraźna jedynie u pacjentów z „niskimi” i „umiarkowanie obniżonymi” wartościami LVEF. Wspomniane trzy grupy nie różnity się pod względem powikłań pooperacyjnych.

Wnioski: Starszy wiek, wspótistniejąca cukrzyca i obniżona wartość LVEF nie wpływają na wczesną i odległą śmiertelność, w tym na wczesne wyniki pooperacyjnej naprawy niedokrwiennej niedomykalności zastawki mitralnej po CABG. Wspótistniejąca cukrzyca zwiększa wskaźniki okołooperacyjnej niedomykalności zastawki mitralnej i wpływa ujemnie na odwracanie przebudowy lewej komory (reverse LV remodeling). Słowa kluczowe: operacje kardiochirurgiczne, naprawa niedokrwiennej zastawki mitralnej, czynniki ryzyka, powikłania. 


\section{Introduction}

Ischemic mitral regurgitation (MR) is caused by local and global myocardial ischemia, leading to altered global and regional myocardial contraction and geometry, which subsequently leads to mitral valve apparatus distortion and insufficiency. Severe MR is usually repaired during coronary artery bypass (CABG) surgery. The surgical approach is expected to lead to reverse left ventricular remodeling after surgery and is associated with improved symptoms and prognosis [1]. It is debatable whether mild MR should be repaired during the $C A B G$ surgery $[2,3]$, although most authors agree that $C A B G$ and mitral valve $(M V)$ repair surgery improve the chances of survival despite the degree of MR $[1,4-7]$. It is obvious that early and late postoperative outcomes depend not only on the type of surgery, but also on the preoperative patient condition, including comorbidities as well. Usually, patients with a coronary artery disease are older and tend to have impaired left ventricular function and the presence of chronic concomitant diseases (such as diabetes mellitus, metabolic syndrome, obesity, chronic obstructive lung disease, etc.) [8]. Though nowadays more and more authors claim good postoperative outcomes in the elderly, Kang et al. found in their study that patients' age was an independent determinant increasing postoperative mortality after CABG followed by MV repair [2]. Preoperative diabetes may also increase the risk of postoperative complications and postoperative mortality. Mihaljevic et al. claim that the risk factors associated with late death include older age and insulin treated diabetes [7]. Mediratta et al. stated in their paper [9] that diabetes (diet and insulin controlled) and LV systolic function were among the most significant factors of long-term survival in patients under the age of 65. A recent extensive study by Ranucci et al. showed that age and LVEF do not increase mortality in low risk patients, but greatly increase mortality in high operative risk patients [8]. Very similar results were obtained by Sadeghi et al., who found that age, poor LV function, and neurologic disorders were risk factors associated with the overall mortality rate [10]. Our study was designed to explore the influence of older age, the presence of diabetes, and LVEF on early and late postoperative outcomes in patients after $C A B G$ and $M V$ repair surgery.

\section{Material and methods}

During the period of 2000-2011, 1385 patients underwent mitral valve repair surgery in Kaunas Hospital, Lithuanian University of Health Sciences. Five hundred and ninety-four of them underwent a coronary artery bypass with concomitant $M V$ repair for ischemic mitral regurgitation $(M R)$. Patients who underwent the emergency procedure and those who had complex surgery (e.g. other heart valves were repaired or replaced and/or a carotid endarterectomy was performed) were excluded. Since the data were collected retrospectively, some of the patients, whose data were incomplete, also were excluded from the study. Finally, retrospective data of 394 patients were analyzed. Patients were divided into groups according to their age and the presence or absence of diabetes mellitus (DM) and LVEF. Based on their age, the patients were divided into group A (70 years and older) and group B (younger than 70 years). Based on DM, patients were divided into those with DM (DM (+)) and without DM (DM (-)). And finally, all patients were grouped according to their LVEF: group I included patients who had poor LVEF ( $<30 \%)$, group II included patients with lowered LVEF ( $50 \%<\operatorname{LVEF} \geq 30 \%$ ), and group III included patients with good LVEF ( $\geq 50 \%$ ). Operative data (cardiopulmonary bypass time, aortic cross-clamp time, postoperative ventilation time, and intensive care unit (ICU) stay) were compared between the groups. Left ventricular systolic and diastolic function and reverse positive remodeling were evaluated analyzing transthoracic echocardiographic (TTE) data before and three months after the surgery and were compared in each group. The left ventricular end diastolic diameter (LVEDD) was evaluated from the parasternal long axis, and LVEF was calculated using Simpson's method. Left ventricular diastolic function was evaluated by measuring the decrease of the early diastolic filling velocity - the deceleration time (DT). The MR grade was evaluated from the apical four-chamber view using color flow Doppler. The rate of postoperative complications (cardiogenic shock, perioperative myocardial infarction, bleeding from gastrointestinal tract, cognitive disorders, stroke, sepsis, deep wound infection), as well as the early and late mortality rate were evaluated and compared between paired groups.

During the surgery, standard endotracheal anesthesia was applied ( $3 \mu \mathrm{g} \cdot \mathrm{kg}^{-1} \cdot \mathrm{h}^{-1}$ fentanyl, $1-4 \mathrm{mg} / \mathrm{h}$ midazolam, and $1.5-2 \%$ minimal alveolar concentration sevoflurane, depending on the hemodynamic status). The cardiopulmonary bypass (CPB) system was filled with $1,500 \mathrm{ml}$ of Ringer's acetate solution and 1,000 units of heparin. A roller pump, a membrane oxygenator (Dideco D703, Mirandola), and a venous reservoir were used for CPB. Coronary artery bypass was performed using the standard technique via mid line sternotomy using cold $\left(4^{\circ} \mathrm{C}\right)$ crystalloid antegrade cardioplegia (St. Thomas solution) and a conventional cardiopulmonary bypass (CPB) using bicaval cannulation. Distal anastomoses were constructed first, the proximal ones on the beating heart and a side clamp on the aorta. Cardiopulmonary bypass was performed under normothermia or deliberate temperature drifting down, but no less than $32^{\circ} \mathrm{C}$ core temperature. A mitral valve annuloplasty was performed, using predominantly the transseptal approach. Mainly, a posterior annuloplasty (from fibrous to fibrous trigone) was performed. Double semi purse 2/0 Ethibond (Johnson \& Johnson) suture, reinforced with Teflon pledgets, was used. Using annuloplasty sutures, the MV annulus was constricted to the size (area) of the anterior mitral valve leaflet. No patient left the operating room with a residual MR grade higher than 1 under transesophageal echocardiography (TEE) control.

After the surgery, patients were transferred to the ICU. During the surgery and in the ICU, conventional hyperglycemia treatment was used in DM (+) patients. When the level of blood glucose was $8-10 \mathrm{mmol} / \mathrm{l}$, patients received an in- 
travenous bolus of four units of insulin every hour. If the blood glucose level increased over $10 \mathrm{mmol} / \mathrm{l}$, a continuous infusion of insulin was administered to keep the blood glucose below $8 \mathrm{mmol} / \mathrm{l}$.

\section{Statistical analysis}

A statistical analysis was performed using the PASW Statistics 18.0 software. The quantitative data are presented as the mean and the standard deviation $(M \pm S D)$. The analyzed parameters were described using the general statistical status, distribution, and symmetry. The tests of Kolmogorov-Smirnov and Shapiro-Wilk were used to check the normal data distribution. The paired-sample $t$ test was used to evaluate the hypothesis. When the statistical hypothesis was verified, the following criterion was used: $p<0.05$ (statistically significant). The $p$-value is the marginal level of statistical significance in hypothesis verification.

\section{Results}

The data of 394 patients were analyzed. $71.57 \%$ (282) of the patients were women and $28.17 \%$ (111) were men. The cardiopulmonary bypass time, the aortic cross-clamp time, the artificial lung ventilation time and the duration of stay in the ICU did not differ between the paired groups (Table I).

\section{Age groups}

Group A included 170 patients aged 70 years and over. The mean age in this group was $74.5( \pm 3.61)$ years. There were significantly more women in group $B$ than in group $A$ (respectively, $77.4 \%$ of women and $22.6 \%$ of men vs. $63.7 \%$ of women and $36.3 \%$ of men, $p<0.05)$. Group B included patients younger than 70 years of age (224 patients). Their mean age was $60.16( \pm 7.02)$ years. The ratio of patients with DM did not differ significantly between the groups (27 [15.9\%] in group A and 48 [21.4\%] in group B, $p>0.05$ ). In relation to the ratio of patients with poor (LVEF $<30 \%$ ), moderately lowered (50\% < LVEF $\geq 30 \%$ ) and good (LVEF $\geq 50 \%$ ) LVEF, the age groups did not differ significantly (respectively, $34.7 \%$ in group A vs. $33.9 \%$ in group $B, p>0.05$; $55.9 \%$ in group $A$ vs. $49.6 \%$ in group $B, p>0.05 ; 9.4 \%$, in group A vs. $16.5 \%$ in group $B, p>0.05$ ) (Table II). The NYHA class before the surgery did not differ significantly between the groups $(2.9 \pm 0.6$ and $2.8 \pm 0.6, p>0.05)$. However, it decreased significantly in groups $A$ and $B$ after the surgery, when compared to that before the surgery (Table III). The comparison of LVEDD and MR before and after the surgery in both groups is given in Table IV. When evaluating echocardiographic data, we detected that MR decreased significantly in both groups following the operation when compared to preoperative data (from $2.8 \pm 0.5$ to $0.98 \pm 0.9$ in group $A$ and from $2.7 \pm 0.6$ to $1.2 \pm 0.9$ in group $B, p<0.001)$. In group $B$, LVEDD decreased significantly $(56.5 \pm 7.3 \mathrm{~mm}$ and $54.1 \pm 8.0$ $\mathrm{mm}$, respectively, $p<0.001)$ while in group A, LVEDD showed only a tendency to decrease after the surgery $(57.5 \pm 7.0 \mathrm{~mm}$ and $56.4 \pm 8.0 \mathrm{~mm}$, respectively, $p>0.05$ ).

In group B, a significant increase in DT was noted $(0.17$ $\pm 0.05 \mathrm{~ms}$ vs. $0.21 \pm 0.06 \mathrm{~ms}, p<0.001)$ after the surgery.

Tab. I. Comparison of operative data between groups

\begin{tabular}{|c|c|c|c|c|c|c|c|c|c|}
\hline & Age groups & Mean \pm SD & $p$ & DM groups & Mean \pm SD & $p$ & LVEF groups & Mean \pm SD & $p$ \\
\hline \multirow[t]{3}{*}{ CPB time [min] } & \multirow[t]{2}{*}{$\begin{array}{l}\text { Group A } \\
(n=170)\end{array}$} & \multirow[t]{2}{*}{$140.6 \pm 46.9$} & \multirow[t]{3}{*}{$>0.05$} & \multirow[t]{2}{*}{$\begin{array}{l}\text { Group DM }(+) \\
\quad(n=75)\end{array}$} & \multirow[t]{2}{*}{$142.7 \pm 51.3$} & \multirow[t]{3}{*}{$>0.05$} & $\begin{array}{l}\text { Group I } \\
(n=135)\end{array}$ & $135.02 \pm 45.4$ & \multirow[t]{3}{*}{$>0.05$} \\
\hline & & & & & & & $\begin{array}{l}\text { Group II } \\
(n=206)\end{array}$ & $142.35 \pm 51.5$ & \\
\hline & $\begin{array}{l}\text { Group B } \\
(n=224)\end{array}$ & $141.4 \pm 52.6$ & & $\begin{array}{c}\text { Group DM }(-) \\
\quad(n=319)\end{array}$ & $140.4 \pm 49.0$ & & $\begin{array}{l}\text { Group III } \\
(n=53)\end{array}$ & $139.27 \pm 42.0$ & \\
\hline \multirow[t]{3}{*}{$\begin{array}{l}\text { Ao cross clamp } \\
\text { time }[\mathrm{min}]\end{array}$} & \multirow[t]{2}{*}{$\begin{array}{l}\text { Group A } \\
(n=170)\end{array}$} & \multirow[t]{2}{*}{$74.9 \pm 20.8$} & \multirow[t]{3}{*}{$>0.05$} & \multirow[t]{2}{*}{$\begin{array}{c}\text { Group DM }(+) \\
\quad(n=75)\end{array}$} & \multirow[t]{2}{*}{$74.3 \pm 22.9$} & \multirow[t]{3}{*}{$>0.05$} & $\begin{array}{l}\text { Group I } \\
(n=135)\end{array}$ & $73.68 \pm 23.9$ & \multirow[t]{3}{*}{$>0.05$} \\
\hline & & & & & & & $\begin{array}{l}\text { Group II } \\
(n=206)\end{array}$ & $77.12 \pm 23.6$ & \\
\hline & $\begin{array}{l}\text { Group B } \\
(n=224)\end{array}$ & $77.1 \pm 29.2$ & & $\begin{array}{c}\text { Group DM }(-) \\
\quad(n=319)\end{array}$ & $76.1 \pm 23.5$ & & $\begin{array}{l}\text { Group III } \\
(n=53)\end{array}$ & $75.73 \pm 24.0$ & \\
\hline \multirow[t]{3}{*}{$\begin{array}{l}\text { Time of ALV } \\
\text { (hours) }\end{array}$} & \multirow[t]{2}{*}{$\begin{array}{l}\text { Group A } \\
(n=170)\end{array}$} & \multirow[t]{2}{*}{$23.0 \pm 46.6$} & \multirow[t]{3}{*}{$>0.05$} & \multirow[t]{2}{*}{$\begin{array}{c}\text { Group DM (+) } \\
\quad(n=75)\end{array}$} & \multirow[t]{2}{*}{$31.9 \pm 66.3$} & \multirow[t]{3}{*}{$>0.05$} & $\begin{array}{l}\text { Group I } \\
(n=135)\end{array}$ & $35.40 \pm 117.4$ & \multirow[t]{3}{*}{$>0.05$} \\
\hline & & & & & & & $\begin{array}{l}\text { Group II } \\
(n=206)\end{array}$ & $30.47 \pm 95.6$ & \\
\hline & $\begin{array}{l}\text { Group B } \\
(n=224)\end{array}$ & $10.4 \pm 139.4$ & & $\begin{array}{c}\text { Group DM }(-) \\
\quad(n=319)\end{array}$ & $29.2 \pm 99.3$ & & $\begin{array}{l}\text { Group III } \\
(n=53)\end{array}$ & $20.27 \pm 33.9$ & \\
\hline \multirow[t]{3}{*}{ ICU stay (days) } & \multirow[t]{2}{*}{$\begin{array}{l}\text { Group A } \\
(n=170)\end{array}$} & \multirow[t]{2}{*}{$4.5 \pm 8.9$} & \multirow[t]{3}{*}{$>0.05$} & \multirow[t]{2}{*}{$\begin{array}{c}\text { Group DM }(+) \\
\quad(n=75)\end{array}$} & \multirow[t]{2}{*}{$4.5 \pm 5.6$} & \multirow[t]{3}{*}{$>0.05$} & $\begin{array}{l}\text { Group I } \\
(n=135)\end{array}$ & $4.82 \pm 8.9$ & \multirow[t]{3}{*}{$>0.05$} \\
\hline & & & & & & & $\begin{array}{l}\text { Group II } \\
(n=206)\end{array}$ & $4.43 \pm 6.4$ & \\
\hline & $\begin{array}{l}\text { Group B } \\
(n=224)\end{array}$ & $5.0 \pm 8.7$ & & $\begin{array}{l}\text { Group DM }(-) \\
\quad(n=319)\end{array}$ & $4.8 \pm 9.4$ & & $\begin{array}{l}\text { Group III } \\
(n=53)\end{array}$ & $3.84 \pm 5.9$ & \\
\hline
\end{tabular}

Ao - aorta, ALV - artificial lung ventilation, CPB - cardiopulmonary bypass, DM (+) - group with diabetes mellitus, DM (-) - group without diabetes mellitus, ICU - intensive care unit, LVEF - left ventricular ejection fraction, SD - standard deviation 
Tab. II. Comparison of preoperative data between age groups

\begin{tabular}{|c|c|c|c|c|c|}
\hline & \multicolumn{2}{|c|}{ Group A ( $\geq 70$ years, $n=170$ ) } & \multicolumn{2}{|c|}{ Group B ( $<70$ years, $n=224)$} & \multirow[t]{2}{*}{$p$} \\
\hline & $n$ & $\%$ & $n$ & $\%$ & \\
\hline LVEF $<30 \%$ & 59 & 34.7 & 76 & 33.9 & $>0.05$ \\
\hline $50 \%<\operatorname{LVEF} \geq 30 \%$ & 95 & 55.9 & 111 & 49.6 & $>0.05$ \\
\hline LVEF $\geq 50 \%$ & 16 & 9.4 & 37 & 16.5 & $>0.05$ \\
\hline $\mathrm{DM}(+)$ & 27 & 15.9 & 48 & 21.4 & $>0.05$ \\
\hline DM (-) & 143 & 84.1 & 176 & 78.6 & $>0.05$ \\
\hline
\end{tabular}

$\overline{\mathrm{DM}}(+)$ - group with diabetes mellitus, DM (-) - group without diabetes mellitus, LVEF - left ventricular ejection fraction

Tab. III. Comparison of heart failure grade (NYHA class) before and after surgery

\begin{tabular}{lllll} 
& & NYHA class before surgery, mean \pm SD & NYHA class after surgery, mean \pm SD & $p$ \\
Age groups & Group A $(n=170)$ & $2.9 \pm 0.6$ & $2.4 \pm 0.7$ & $<0.05$ \\
\cline { 2 - 4 } & Group B $(n=224)$ & $2.8 \pm 0.6$ & $2.6 \pm 0.7$ & $<0.05$ \\
\hline DM groups & Group DM $(+)(n=75)$ & $2.9 \pm 0.6$ & $2.4 \pm 0.7$ & $<0.05$ \\
\cline { 2 - 4 } & Group DM $(-)(n=319)$ & $2.8 \pm 0.6$ & $2.6 \pm 0.7$ & $>0.05$ \\
\hline LVEF groups & Group I $(n=135)$ & $3.09 \pm 0.6$ & $2.7 \pm 0.7$ & $<0.05$ \\
\cline { 2 - 4 } & Group II $(n=206)$ & $2.4 \pm 0.6$ & $<0.05$ \\
\cline { 2 - 4 } & Group III $(n=53)$ & $2.8 \pm 0.6$ & $2.3 \pm 0.4$ & $<0.05$ \\
\hline
\end{tabular}

DM (+) - group with diabetes mellitus, DM (-) - group without diabetes mellitus, LVEF - left ventricular ejection fraction, NYHA - New York Heart Association, SD - standard deviation

Tab. IV. Comparison of left ventricular end diastolic diameter and mitral regurgitation before and after surgery

\begin{tabular}{|c|c|c|c|c|c|c|c|c|c|}
\hline & Age groups & $\begin{array}{l}\text { Mean } \pm \text { SD } \\
\text { before and } \\
\text { after surgery }\end{array}$ & $p$ & DM groups & $\begin{array}{l}\text { Mean } \pm \text { SD } \\
\text { before and } \\
\text { after surgery }\end{array}$ & $p$ & LVEF groups & $\begin{array}{l}\text { Mean } \pm \text { SD } \\
\text { before and } \\
\text { after surgery }\end{array}$ & $p$ \\
\hline \multirow[t]{6}{*}{ LVEDD (mm) } & \multirow{4}{*}{$\begin{array}{l}\text { Group A } \\
(n=170)\end{array}$} & \multirow[t]{2}{*}{$57.5 \pm 7.0$} & \multirow[t]{4}{*}{$>0.05$} & \multirow{4}{*}{$\begin{array}{c}\text { Group DM } \\
(+) \\
(n=75)\end{array}$} & \multirow[t]{2}{*}{$57.2 \pm 7.2$} & \multirow[t]{4}{*}{$>0.05$} & \multirow{2}{*}{$\begin{array}{c}\text { Group I } \\
(n=135)\end{array}$} & $61.5 \pm 7.1$ & \multirow[t]{2}{*}{$>0.05$} \\
\hline & & & & & & & & $60.2 \pm 7.3$ & \\
\hline & & \multirow[t]{2}{*}{$56.4 \pm 8.0$} & & & \multirow[t]{2}{*}{$55.7 \pm 7.1$} & & \multirow{2}{*}{$\begin{array}{c}\text { Group II } \\
(n=206)\end{array}$} & $55.5 \pm 6.5$ & \multirow[t]{2}{*}{$<0.05$} \\
\hline & & & & & & & & $53.8 \pm 7.3$ & \\
\hline & \multirow{2}{*}{$\begin{array}{l}\text { Group B } \\
(n=224)\end{array}$} & $56.5 \pm 7.3$ & \multirow[t]{2}{*}{$<0.05$} & \multirow{2}{*}{$\begin{array}{c}\underset{(-)}{\text { Group } D M} \\
(n=319) \\
\end{array}$} & $57.1 \pm 7.2$ & \multirow[t]{2}{*}{$<0.05$} & \multirow{2}{*}{$\begin{array}{c}\text { Group III } \\
(n=53)\end{array}$} & $53.5 \pm 5.9$ & \multirow[t]{2}{*}{$>0.05$} \\
\hline & & $54.1 \pm 8.0$ & & & $55.6 \pm 8.3$ & & & $52.7 \pm 8.9$ & \\
\hline \multirow[t]{6}{*}{ MR (grade) } & \multirow{4}{*}{$\begin{array}{l}\text { Group A } \\
(n=170)\end{array}$} & $2.8 \pm 0.5$ & \multirow[t]{4}{*}{$<0.05$} & \multirow{4}{*}{$\begin{array}{c}\text { Group DM } \\
(+) \\
(n=75)\end{array}$} & $2.6 \pm 0.5$ & \multirow[t]{4}{*}{$<0.05$} & \multirow{2}{*}{$\begin{array}{c}\text { Group I } \\
(n=135)\end{array}$} & $2.7 \pm 0.6$ & \multirow[t]{2}{*}{$<0.05$} \\
\hline & & & & & & & & $1.0 \pm 1.0$ & \\
\hline & & \multirow[t]{2}{*}{$0.98 \pm 0.9$} & & & $1.2 \pm 0.9$ & & \multirow{2}{*}{$\begin{array}{c}\text { Group II } \\
(n=206)\end{array}$} & $2.7 \pm 0.5$ & \multirow[t]{2}{*}{$<0.05$} \\
\hline & & & & & & & & $1.0 \pm 0.9$ & \\
\hline & \multirow{2}{*}{$\begin{array}{l}\text { Group B } \\
(n=224)\end{array}$} & $2.7 \pm 0.6$ & \multirow[t]{2}{*}{$<0.05$} & \multirow{2}{*}{$\begin{array}{c}\text { Group DM } \\
(-) \\
(n=319)\end{array}$} & $2.8 \pm 0.6$ & \multirow[t]{2}{*}{$<0.05$} & \multirow{2}{*}{$\begin{array}{l}\text { Group III } \\
(n=53)\end{array}$} & $2.9 \pm 0.5$ & \multirow[t]{2}{*}{$<0.05$} \\
\hline & & $1.2 \pm 0.9$ & & & $1.1 \pm 0.9$ & & & $1.4 \pm 1.0$ & \\
\hline
\end{tabular}

DM (+) - with diabetes mellitus, DM (-) - without diabetes mellitus, LVEDD - left ventricular end diastolic diameter, LVEF - left ventricular ejection fraction, $\mathrm{MR}$ - mitral regurgitation, SD - standard deviation

However, there were no differences of echocardiographic data between the age groups.

\section{The groups according to the presence of diabetes mellitus}

Group DM (+) included 75 patients and group DM (-) included 319 patients. The DM (-) group included significantly more men compared to the DM (+) group $(75.1 \%$ men and $24.9 \%$ women vs. $57.7 \%$ men and $42.3 \%$ women, respectively; $p<0.05)$. The NYHA class did not differ between the groups before the surgery $(2.8 \pm 0.7$ and $2.9 \pm 0.4$, $p>0.05)$. The groups did not differ in the number of grafts performed. In the majority of patients in both groups, three grafts $(72.1 \%$ in group DM (-) and $75.6 \%$ in group DM (+), 
$p>0.05)$ were performed, while two grafts were performed in $23.7 \%$ of patients in group DM (-) and $21.8 \%$ in group $\mathrm{DM}(+)(p>0.05)$. Four grafts were performed only in $1.9 \%$ of patients in group DM (-) and $1.3 \%$ in group DM (+) $(p>0.05)$. The NYHA class decreased significantly $(p<0.05)$ (Table III). Left ventricular end diastolic diameter and $M R$ before and after the surgery in both groups are given in Table IV. The comparison of echocardiographic data before and after the surgery revealed a significant decrease in LVEDD, left ventricular end systolic diameter (LVESD) (from $46.7 \pm 9.9 \mathrm{~mm}$ to $43.0 \pm 14.0 \mathrm{~mm}$, $p<0.05)$, and the MR grade $(2.8 \pm 0.6$ vs. $1.1 \pm 0.9, p<0.001)$ in group DM (-) (Table IV). In group DM (+), only the MR grade decreased significantly $(2.6 \pm 0.5$ vs. $1.2 \pm 0.9$, $p<0.001)$ and a tendency for a LVEDD decrease was observed (Table IV).

\section{The different LVEF groups}

Group I included 135 patients, group || 206 patients, and group III 53 patients. The groups did not differ according the number of grafts performed during the surgery. In the majority of patients, three grafts were performed (group I $77.5 \%$, group $I-70.5 \%$, group $I I-63.6 \%, p>0.05$ ), while two grafts were performed in $18 \%$ in group I, $25.7 \%$ in group II, and $36.4 \%$ in group III $(p>0.05)$. In all three groups the NYHA class decreased significantly after the surgery (Table III). Left ventricular end diastolic diameter and the MR grade before and after the surgery in all groups are given in Table IV. The analysis of echocardiographic data indicated that in group I after the surgery, LVEF increased (from $23.6 \pm 4.3$ to $29.7 \pm 9.4 \%, p<0.001)$ and MR significantly decreased. In group II, MR and LVEDD decreased significantly (Table IV) and DT increased significantly (from $0.19 \pm 0.05 \mathrm{~ms}$ to 0.24 $\pm 0.07 \mathrm{~ms}, p<0.001$ ) after the surgery, whereas in group III, only the MR grade decreased significantly ( $2.9 \pm 0.5$ vs. 1.4 $\pm 1.0, p<0.001)$.

\section{Postoperative complications, early and late mortality rate}

The overall rate of postoperative cardiogenic shock was $65.91 \%$. $27.6 \%$ of patients required low doses of inotropic medications, $19.3 \%$ required medium doses, and $19.0 \%$ required high doses of inotropic medications. Perioperative myocardial infarction was detected in $4.5 \%$ of patients, bleeding from $\mathrm{Gl}$ tract in $2.26 \%$ of patients, postoperative cognitive dysfunction in $1.7 \%$, and stroke in $2.5 \%$ of patients. $5.36 \%$ of patients had a deep wound infection and $3.4 \%$ of patients had sepsis. The rate of early mortality was $16.24 \%$, while the rate of late mortality was $2.03 \%$.

When postoperative complications were compared between paired groups, a significantly higher perioperative myocardial infarction rate was found in group DM (+) as compared to group DM (-) $(10.3 \%$ vs. $3.1 \%$, respectively, $p<0.01)$. Moreover, in group A, a significantly higher incidence of sepsis ( $4.9 \%$ in group B vs. $0.6 \%$ in group A, $p<0.05$ ) and deep wound infection $(8.0 \%$ in group $B$ vs. $1.8 \%$ in group $A, p<0.05)$ was observed. The rate of other com- plications, as well as early and late mortality, did not differ between the paired groups.

\section{Discussion}

Some authors recommend performing CABG as a standalone procedure in patients with mild $M R$ and increased perioperative risk factors, such as old age, the presence of diabetes and poor LV systolic function. They refer to the extended length of the surgery and the questionable improvement of long-term outcomes [1, 2, 7, 11, 12]. In our study, we compared the impact of high operative risk factors (age over 70 years, presence of DM, poor LVEF) on the outcomes of CABG and MV repair. The results of our study indicate that older age, concomitant diabetes, and lowered or poor LVEF did not increase early and late postoperative mortality after CABG and the MV repair surgery in patients with ischemic heart disease and ischemic MR. Moreover, they did not significantly influence the time of artificial lung ventilation or the length of stay in the ICU after the surgery.

Having compared postoperative complications in age groups, we found that infectious complications had a higher rate in the group of younger patients. The ratio of patients with DM in both groups was similar and did not differ statistically significantly. Many postoperative complications after the cardiac surgery with CPB are related to the systemic inflammatory response syndrome (SIRS). Cardiopulmonary bypass may itself provoke a systemic inflammatory response, caused by blood contact with the artificial bypass surface, cold cardiac ischemia, and hypothermia [13, 14]. $T$ cells are mainly involved in an acute immune response by secreting cytokines. They bind to specific receptors on target cells and call into play many other cells and substances, including elements of the inflammatory response. Older age is associated with a chronic low grade inflammation process, caused by significantly reduced levels of $\mathrm{T}$ cells, while younger age is usually associated with better reactivity of the immune system $[15,16]$. In any case, we cannot explain the results we obtained by the patients' age only.

Three-month postoperative outcomes were favorable in both age groups. After the operation, the functional capacity of the cardiovascular system (expressed as the NYHA class) increased in both age groups. The surgery was effective and MR decreased significantly in both groups. Although in the group of younger patients, LVEDD had only a tendency to decrease, the deceleration time increased and showed an improvement in the LV diastolic function. In the group of older patients, the reversible remodeling of LV is confirmed by decreased LVEDD.

Comparing the patients with and without diabetes, we found that despite good surgical results (MR decreased significantly from grade II-III to grade I in both groups), the functional capacity of the cardiovascular system did not improve in patients with diabetes (the NYHA class did not change significantly). Moreover, reversible remodeling of LV was not found in patients with diabetes, although a tendency of LVEDD to decrease was observed. Addition- 
ally, a higher incidence of perioperative MI was detected in the diabetes group of patients. Diabetes causes not only vascular disorders in the heart, but also disorders in the entire body. There is another type of heart disease related to diabetes and the metabolic syndrome which is not associated with hypertension or coronary artery disease [17]. Diabetic cardiomyopathy is characterized by an impaired diastolic relaxation time (diastolic dysfunction) and reduced contractility (systolic dysfunction). It is characterized by a slow reduction of systolic function. The diastolic dysfunction is the initial heart lesion and when the systolic dysfunction develops, the diastolic dysfunction is usually already significantly advanced. The underlying pathophysiological mechanisms involve interstitial and perivascular fibrosis due to necrotic and increased apoptotic myocardial cell death, impaired calcium reuptake caused by functional alterations in cellular ion channels, structural and functional changes in small coronary arteries (atheromas are more extensive and diffuse and involve small vessels, capillary basement membranes are thickened, microaneurysms are formed), and cardiac autonomic neuropathy [18]. The latter leads to parasympathetic-sympathetic nervous system imbalance, when the tone of the parasympathetic system is decreased and the sympathetic tone is relatively increasing. Preexisting diabetic cardiomyopathy makes the heart more susceptible to ischemia [19]. So, it may be supposed that diabetic cardiomyopathy determined residual LV remodeling and the remaining high NYHA functional class, just as it can predispose to a higher incidence of perioperative $M I$ in our study $[20,21]$.

When patients were grouped according to LVEF, it appeared that the functional cardiovascular status improved in all three groups after the surgery. Echocardiographic data also showed that postoperative results improved in all three groups, although to a different degree. In patients with poor LVEF, a significant improvement in systolic function was found. In the other two groups, the ejection fraction did not show such an improvement, probably because the baseline LVEF was better and the change was not statistically significant. Although MR decreased in all groups, reversible positive LV remodeling and an improvement of diastolic function were detected only in patients with moderately lowered LVEF. We suppose that precisely this group of patients can benefit the most from CABG and MV repair surgery.

The main limitation of the present study is its retrospective design. As data were analyzed retrospectively, we had to exclude patients with incomplete data, so the sample size was limited. These data reflect the experience of a single center, which may limit the study's more general nature.

\section{Conclusions}

Elderly age and a lowered left ventricular ejection fraction did not worsen early postoperative outcomes and did not increase early and late mortality after mitral valve repair for ischemic mitral regurgitation. The presence of dia- betes did not influence early and late mortality after mitral valve repair for ischemic mitral regurgitation. The presence of diabetes increased the perioperative myocardial infarction rate, while younger age was associated with an increased risk of infectious complications after mitral valve repair for ischemic mitral regurgitation. Regardless of reduced mitral regurgitation, reversible remodeling of the left ventricle was observed only in the group of patients without diabetes and with a moderately lowered left ventricular ejection fraction.

\section{Disclosure}

Authors report no conflict of interest.

\section{References}

1. Crabtree TD, Bailey MS, Moon MR, Munfakh N, Pasque MK, Lawton JS, Moazami N, Aubuchon KA, Al-Dadah AS, Damiano RJ Jr. Recurrent mitral regurgitation and risk factors for early and late mortality after mitral valve repair for functional ischemic mitral regurgitation. Ann Thorac Surg 2008; 85: 1537-1542.

2. Kang DH, Kim MJ, Kang SJ, Song JM, Song H, Hong MK, Choi KJ, Song JK, Lee JW. Mitral valve repair versus revascularization alone in the treatment of ischemic mitral regurgitation. Circulation 2006; 114 (1 Suppl): 1499-503.

3. Markar SR, Low DE. Physiology, not chronology, dictates outcomes after esophagectomy for esophageal cancer: outcomes in patients 80 years and older. Ann Surg Oncol 2013; 20: 1020-1026.

4. Antunes MJ. Mild-moderate ischemic mitral regurgitation: should it be treated together with CABG? Eur J Cardiothorac Surg 2006; 29: 353-354.

5. Bax JJ, Braun J, Somer ST, Klautz R, Holman ER, Versteegh MI, Boersma E, Schalij MJ, van der Wall EE, Dion RA. Restrictive annuloplasty and coronary revascularization in ischemic mitral regurgitation results in reverse left ventricular remodeling. Circulation 2004; 110: ॥103-108.

6. Lam BK, Gillinov AM, Blackstone EH, Rajeswaran J, Yuh B, Bhudia SK, McCarthy PM, Cosgrove DM. Importance of moderate ischemic mitral regurgitation. Ann Thorac Surg 2005; 79: 462-470.

7. Mihaljevic T, Lam BK, Rajeswaran J, Takagaki M, Lauer MS, Gillinov AM, Blackstone EH, Lytle BW. Impact of mitral valve annuloplasty combined with revascularization in patients with functional ischemic mitral regurgitation. J Am Coll Cardiol 2007; 49: 2191-2201.

8. Ranucci M, Castelvecchio S, Conte M, Megliola G, Speziale G, Fiore F, Guarracino F, Scolletta S, Escobar RM, Falco M, Bignami E, Landoni G. The easier, the better: age, creatinine, ejection fraction score for operative mortality risk stratification in a series of 29,659 patients undergoing elective cardiac surgery. J Thorac Cardiovasc Surg 2011; 142: 581-586.

9. Mediratta N, Chalmers J, Pullan M, McShane J, Shaw M, Poullis M. In-hospital mortality and long-term survival after coronary artery bypass surgery in young patients. Eur J Cardiothorac Surg 2013; 43: 1014-1021.

10. Sadeghi MM, Arasteh M, Gharipour M, Nilfroush P, Shamsolketabi H, Etesampour A, Sadeghi FM, Kiani A, Sadeghi PM, Farahmand N. Evaluation of accuracy of Euroscore risk model in prediction of perioperative mortality after coronary bypass graft surgery in Isfahan. J Res Med Sci 2011; 16: 787-792.

11. De Bonis M, Taramasso M, Verzini A, Ferrara D, Lapenna E, Calabrese MC, Grimaldi A, Alfieri O. Long-term results of mitral repair for functional mitral regurgitation in idiopathic dilated cardiomyopathy. Eur J Cardiothorac Surg 2012; 42: 640-646.

12. Nloga J, Henaine R, Vergnat M, Wautot F, Desebbe O, Robin J, Ninet J, Obadia JF. Mitral valve surgery in octogenarians: should we fight for repair? A survival and quality-of-life assessment. Eur J Cardiothorac Surg 2011; 39: 875-880.

13. Baehner T, Boehm O, Probst C, Poetzsch B, Hoeft A, Baumgarten G, Knuefermann P. Cardiopulmonary bypass in cardiac surgery. Anaesthesist 2012; 61: 846-856.

14. Cusi MG, Martorelli B, Di Genova G, Terrosi C, Campoccia G, Correale P. Age related changes in $T$ cell mediated immune response and effector memory to Respiratory Syncytial Virus (RSV) in healthy subjects. Immun Ageing 2010; 7: 14. 
15. Alonso-Fernandez P, De la FM. Role of the immune system in aging and longevity. Curr Aging Sci 2011; 4: 78-100.

16. Jenny NS. Inflammation in aging: cause, effect, or both? Discov Med 2012; 13: 451-460.

17. Osman KA, Ahmed MH. Moderate ischemic mitral regurgitation (IMR) and metabolic syndrome: where are we now and where are we going? Cardiovasc Diabetol 2006; 5: 24.

18. Voulgari C, Papadogiannis D, Tentolouris N. Diabetic cardiomyopathy: from the pathophysiology of the cardiac myocytes to current diagnosis and management strategies. Vasc Health Risk Manag 2010; 6: 883-903.
19. Boudina S, Abel ED. Diabetic cardiomyopathy, causes and effects. Rev Endocr Metab Disord 2010; 11: 31-39.

20. Mandavia CH, Aroor AR, Demarco VG, Sowers JR. Molecular and metabolic mechanisms of cardiac dysfunction in diabetes. Life Sci 2013; 92: 601-608.

21. Seferović PM, Milinković I, Ristić AD, Seferović Mitrović JP, Lalić K, Jotić A, Kanjuh V, Lalić N, Maisch B. Diabetic cardiomyopathy: ongoing controversies in 2012. Herz 2012; 37: 880-886. 